\title{
Glandular Trichomes: A Helpful Taxonomic Character for Artemisia nova (Black Sage- brush)
}

\author{
RICK G. KELSEY
}

\begin{abstract}
The visibility of leaf glandular trichomes with $10 \mathrm{x}$ magnification was examined for 7 sagebrush taxa. In 75\% of the Artemisia nova plants the glands were easily observed protruding through a layer of nonglandular trichomes (hairs). On $A$. arbuscula and the 3 subspecies of $A$. tridentata the glands were covered by the hairs and were not visible. These structures can be observed in the field with a hand lens and provide a supportive characteristic for the identification of A. nove.
\end{abstract}

The taxonomic status of Artemisia nova Nelson (black sagebrush), like many North American species of Artemisia, has been revised frequently since its initial description in 1900. Ranked as a species by Nelson (1900) and Rydberg (1916), it was reduced to a subspecies of $A$. tridentata Nutt. (big sagebrush) by Hall and Clements (1923) and later to a subspecies of $A$. arbuscula Nutt. (low sagebrush) by Ward (1953). Beetle (1960), elevated it back to the species level and reaffirmed that position a decade later (Beetle 1970). Recently it was recognized as a well-defined taxon both morphologically and ecologically in a systematics and anatomical study of the subgenus Tridentatae by Shultz (1983).

Difficulty associated with the identification of Artemisia taxa has been emphasized by West et al. (1978). They separated $A$. arbuscula, $A$. nova and the 3 subspecies of $A$. tridentata (tridentata, vaseyana (Rydb.) Beetle and wyomingensis Beetle and Young) by morphological traits and independently by paper chromatography. After comparing the proficiency of identification by these 2 sets of characteristics, chromatography was selected as the more objective and reliable. With chromatography as the final arbiter, $A$. tridentata ssp. tridentata and $A$. arbuscula were the 2 species most often confused with $A$. nova morphologically. Artemisia nova was most often misidentified as $A$. arbuscula.

Brunner (1972) reported his observations for Artemisia in Nevada. He noted black glands visible on $A$. nova and white glands on $A$. arbuscula when viewed with a $10 x$ lens, but gave no discussion of their utility as taxonomic characters. The leaf epidermis of all sagebrush species is covered with glandular (Diettert 1938, Kelsey and Shafizadeh 1980, Shultz 1983) and nonglandular trichomes (except A.pygmaea). On A. nova the glandular trichomes (glands) appear to be more conspicuous than they are on any other taxa. The objective of this study was to examine sagebrush leaf trichomes under 10x magnification to determine their value for identifying $A$. nowa.

\section{Methods}

The plant material used in this study included herbarium specimens from the University of Montana (MONTU); The Rocky Mountain Herbarium, University of Wyoming (RM); and The New York Botanical Garden (NY). Additional leaf samples were obtained from E. Durant McArthur, Intermountain Forest and Range Experiment Station, Shrub Sciences Laboratory, Provo, Utah, and Neil E. West, Utah State University, Logan.

A minimum of 10 vegetative leaves were closely examined for

\footnotetext{
Author is research associate professor, Department of Chemistry, University of Montana, Missoula 59812.

Manuscript accepted November 18, 1983.
}

each plant with a dissecting microscope (10x magnification). Our previous study found equal numbers of glands on the adaxial and abaxial leaf surfaces (Kelsey and Shafizadeh 1980). The visibility of glandular trichomes over the entire surface of each leaf was scored into 1 of 3 categories: (1) inconspicuous-glands occurred below the layer of nonglandular trichomes (hairs). Frequently, the hairs were so dense that no glands were observed. If hair density was sparse, the glands still were not easily recognizable (Fig. 1);(2) conspicuous--glands protruded into the nonglandular layer and some were esily recognized. When the hairs were very dense, tops of the glands sometimes appeared as small dots or openings. Glands seldom extended beyond the nonglandular layer; and (3) very conspicuous - the glands formed distinct spots or openings in the hairs and sometimes extended beyond with a drop-like appearance. The glands were easily observed (Fig. 1).

After the observations began, subtle but recognizable differences became apparent in the layer of nonglandular trichomes. They were scored for each leaf into 1 of 3 groups: (1) fluffy-hairs were separate from each other, not stuck or matted together, and individual trichomes were easily seen. Density and depth of trichomes were not a criteria, as they varied considerably (Fig. 1); (2) stucknonglandular trichomes were stuck together, individual hairs not easily noticeable, and; (3) matted - all trichomes were tightly stuck together, matted to the epidermis in spots and not individually recognizable as hairs (Fig. I).

To maintain objectivity, the leaves were examined without knowledge of their prior identity on the herbarium label. Each specimen was then identified based on the morphological characters available.

\section{Results and Discussion}

Over 1,200 plants from 7 taxa were examined, with specimens representing the geographic ranges of each (Table 1). Although gland visibility was scored into 1 of 3 categories, the 2 extremes, inconspicuous and very conspicuous, were most diagnostic for species separation. Seventy-five percent of the $A$. nova plants had very conspicuous glandular trichomes compared with $A$. arbuscula and the 3 subspecies of $A$. tridentata that all had at least $90 \%$ of their individuals with inconspicuous glands. Differences in nonglandular trichomes, although more subtle and difficult to detect, also were apparent. Stuck or matted hairs were observed almost exclusively on $A$. nova (82\%), with only $4 \%$ in $A$. tripartita Rydb. ssp. tripartita (three-tip sagebrush) and $1 \%$ or less on the other 5 taxa. This feature may be caused by sticky terpenoid constituents (Kelsey and Shafizadeh 1980) released from glands that ruptured during development.

Within-plant variation did occur but was not excessive. Approximately $80 \%$ of the plants in all taxa except $A$. longiloba and $A$. tripartita spp. tripartita showed no variation in gland visibility between leaves, or had only 1 leaf that differed. The latter 2 taxa expressed the greatest intraplant variation, with $80 \%$ of their individuals having 3 or fewer inconsistent leaves. To reduce errors from this source, numerous leaves should be examined from throughout the crown or specimen. 


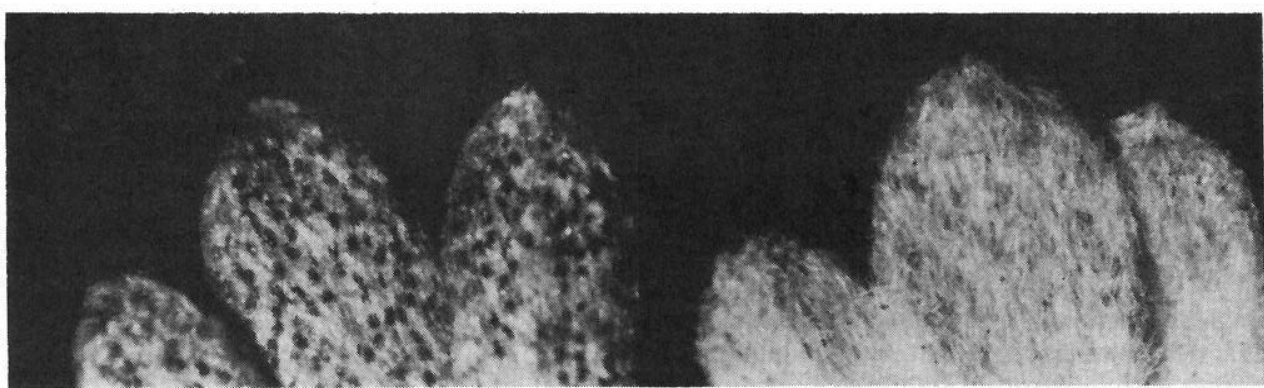

Fig. 1. Left: A. nova with conspicuous glandular trichomes protruding through nonglandular trichomes that are stuck together and not individually recognizable. Right: A. arbuscula, glandular trichomes inconspicuous beneath a dense layer of individually visible nonglandular trichomes with a fluffy appearance.

Table 1. The visibility of glandular trichomes on vegetative leaves with $10 x$ magnification.

\begin{tabular}{|c|c|c|c|c|c|c|c|c|c|c|c|c|}
\hline \multirow[b]{3}{*}{ State } & \multicolumn{12}{|c|}{ Species } \\
\hline & \multicolumn{4}{|c|}{$\mathrm{Aaa}^{1}$} & \multicolumn{4}{|c|}{$\mathrm{Al}$} & \multicolumn{4}{|c|}{ An } \\
\hline & $\mathrm{IC}^{2}$ & \multicolumn{2}{|c|}{$\mathrm{C}$} & VC & IC & \multicolumn{2}{|c|}{$\mathrm{C}$} & VC & IC & \multicolumn{2}{|l|}{$\mathrm{C}$} & VC \\
\hline \multicolumn{13}{|c|}{ No. of Plants } \\
\hline Arizona & - & \multicolumn{2}{|c|}{$1^{3,5}$} & - & - & & \multicolumn{2}{|r|}{ - } & 1 & \multicolumn{2}{|l|}{1} & 3 \\
\hline California & 13 & \multicolumn{2}{|c|}{3} & - & $1^{3,5}$ & & \multicolumn{2}{|r|}{ - } & 3 & - & & 7 \\
\hline Canada & - & & & - & - & & & - & - & - & & - \\
\hline Colorado & $1^{3,5}$ & & & - & 7 & & & 1 & - & 3 & & 5 \\
\hline Idaho & 30 & & & 1 & 12 & & & - & 3 & 3 & & 12 \\
\hline Mexico & - & & & - & - & & & - & - & - & & - \\
\hline Montana & 13 & & & - & 18 & & & 1 & - & 6 & & 18 \\
\hline Nebraska & - & & & - & - & & & - & - & - & & - \\
\hline Nevada & 42 & & & - & 6 & & & - & 7 & - & & 17 \\
\hline New Mexico & $1^{3,5}$ & & & - & - & & & - & - & - & & 2 \\
\hline North Dakota & - & & & - & - & & & - & - & - & & - \\
\hline Oregon & 17 & & & - & 7 & & & - & 1 & - & & 2 \\
\hline South Dakota & - & & & - & - & & & - & - & - & & - \\
\hline Utah & 28 & & & - & 2 & & & - & 3 & 6 & & 19 \\
\hline Washington & 4 & & & - & - & & & - & - & - & & - \\
\hline Wyoming & 11 & & & - & 10 & & & 1 & 1 & $\cdot-$ & & 29 \\
\hline Total Plants & 160 & 1 & & 1 & 63 & 15 & & 3 & 19 & 19 & & 114 \\
\hline$\%$ within taxa & 92 & & & 1 & 74 & 2 & & 4 & 13 & 13 & & 75 \\
\hline & & tptp & & & Atv & & & Att & & & Atw & \\
\hline State & IC & $\mathrm{C}$ & $\mathrm{VC}$ & IC & $\mathrm{C}$ & $\mathrm{VC}$ & IC & $\mathrm{C}$ & $\mathrm{VC}$ & IC & $\mathrm{C}$ & $\overline{\mathrm{VC}}$ \\
\hline & & & & & & Plants & & & & & & \\
\hline Arizona & - & - & - & $4^{3}$ & - & - & 4 & 1 & - & 4 & - & - \\
\hline California & - & - & - & 38 & 1 & - & 21 & 2 & - & $1^{5}$ & - & 1 \\
\hline Canada & - & 2 & - & 1 & - & - & 3 & 1 & - & $\cdot 1^{4,5}$ & - & - \\
\hline Colorado & $1^{3,5}$ & - & - & 29 & 1 & - & 10 & - & - & 3 & - & 1 \\
\hline Idaho & 10 & 11 & 2 & 33 & 4 & - & 38 & 4 & - & 30 & - & - \\
\hline Mexico & - & - & - & - & - & - & 7 & - & - & - & - & - \\
\hline Montana & 20 & 7 & 1 & 128 & 24 & - & 10 & 1 & - & 33 & 6 & - \\
\hline Nebraska & - & - & - & $1^{4}$ & - & - & - & - & - & - & - & - \\
\hline Nevada & 1 & - & - & 15 & 1 & - & 23 & - & - & 9 & - & - \\
\hline New Mexico & - & - & - & $1^{5}$ & - & - & 3 & - & - & - & - & - \\
\hline North Dakota & - & - & - & - & - & - & - & - & - & $3^{5}$ & - & - \\
\hline Oregon & 4 & 2 & - & 19 & 2 & - & 19 & 2 & - & 4 & 2 & - \\
\hline South Dakota & - & - & - & - & - & - & - & - & - & $6^{5}$ & - & - \\
\hline Utah & - & 1 & - & 34 & 5 & - & 20 & 4 & - & 6 & 1 & 1 \\
\hline Washington & 5 & 2 & - & 6 & - & - & 9 & 3 & - & $8^{4,5}$ & - & - \\
\hline Wyoming & 9 & 2 & - & 57 & 3 & - & 18 & - & - & 26 & 1 & - \\
\hline Total Plants & 50 & 27 & 3 & 366 & 41 & 0 & 185 & 18 & 0 & 134 & 10 & 1 \\
\hline$\%$ within taxa & 63 & 34 & 4 & 90 & 10 & 0 & 91 & 9 & 0 & 92 & 7 & 1 \\
\hline
\end{tabular}

Aaa, Artemisia arbuscula ssp. arbuscula; Al, A. longiloba; An, A. nova; Atptp, A. tripartita ssp. tripartita; Atv, A. tridentata ssp. vaseyana; Att, A. tridentata ssp. tridentata; Atw, A. tridentata ssp. wyomingensis; as identified by the author.

${ }^{2} \mathrm{IC}$, inconspicuous; C, conspicuous; VC, very conspicuous.

${ }^{3}$ Not in this state according to Beetle 1960.

${ }^{4}$ Not in this state according to Harvey 1981.

${ }^{5}$ Not in this state according to Shultz 1983.

Most discrepencies in distribution arise from the inability to accurately include in a map all the outlying populations of a taxa at the limits of its boundaries. 
The occurrence of whole plant color forms (glossy, dark to pale green, or silvery-canescent) was noted first by Beetle in 1960 and confirmed by numerous other observers (Young and Asplund 1964, Winward and Tidale 1969, Brunner 1972). In addition to being morphologically separable, they also differ in animal utilization; the silvery-canescent form is heavily grazed, whereas the glossy green plants are grazed less (Brunner 1972, McArthur et al. 1979). The character of the hairs determines the 2 color forms.

When these structures are dense and fluffy, covering the glandular trichomes, the plant is silvery-canescent; conversely, when they are stuck or matted together with protruding glandular trichomes, the plant is glossy green. A small proportion (13\%) of $A$. nova plants had fluffy hairs and nonconspicuous glands, like those observed on $A$. arbuscula (Fig. 1). This condition caused the most common identification error. Winward and Tisdale (1969) noted that the silvery-canescent form of $A$. nova resembled $A$. arbuscula and was easily confused with it. A high proportion of silvery-canescent $A$. nova occurs in Nevada and California (Table 1).

Brunner (1972) reported that $A$. arbuscula ssp. arbuscula may have white glands. In this study, they were observed on $5 \%$ of the $A$. arbuscula ssp. arbuscula, $3 \%$ of the $A$. nova, and $1 \%$ or less for the other taxa. Most specimens exhibiting white glands came from Nevada, Utah,or Idaho. This character was not taxonomically useful.

Varying shades of yellow, orange or red glands occurred infrequently in about $2 \%$ of the plants. This was more common in the older specimens as a result of terpenoid aging in the glands. The color made them easier to see compared to transparent glands on fresh tissue, and was taken into account when examining these specimens.

Conspicuous glandular trichomes were observed on $A$. nova plants from all states within its geographic range, and they are visible in the field with a hand lens. The importance of field identification for sagebrush species has been emphasized (Beetle 1970, Kelsey et al. 1976, Beetle and Johnson 1982) and is being stressed here. It provides a comprehensive set of characteristics (morphological, geographical, and ecological) often with subtle differences and extensive variation. Uncertainties from variation can be minimized in the field.

Chemical characteristics are also useful in separating and identifying sagebrush taxa (Young 1965, Holbo and Mozingo 1965, Brunner 1972, Hanks et al. 1973, Kelsey et al. 1976, Winward and Tisdale 1977, West et al. 1978, Kelsey 1982) and should not reduce the importance of field identification. Chemical analysis is a good check for field determinations and can be very helpful in eliminating problems caused by morphological variation.

The visibility of glandular and nonglandular trichomes on the leaves of sagebrush with $10 x$ magnification can be used as an additional taxonomic characteristic for $A$. nova. In combination with the other diagnostic features they should help reduce ficld identification errors caused by morphological variation. They also provide strong support for $A$. nova as a distinct species.

\section{Literature Cited}

Beetle, A.A. 1960. A study of sagebrush, the section Tridentatae of Artemisia. Univ. Wyoming Agr. Exp. Sta. Bull. 368.

Beetle, A.A. 1970. An ecological contribution to the taxonomy of Artemisia. Madroño 20:385-386.

Beetle, A.A., and K.L. Johnson. 1982. Sagebrush in Wyoming. Univ. Wyoming Agr. Exp. Sta. B-779.

Brunner, J.R. 1972. Observations on Artemisia in Nevada. J. Range Manage. 25:205-208.

Diettert, R.A. 1938. The morphology of Artemisia tridentata Nutt. Lloydia 1:3-74.

Hall, H.M., and F.E. Clements. 1923. The phylogenetic method in taxonomy. The North American species of Artemisia, Chrysothamnus, and Atriplex. Carnegie Inst. Wash. Pub. 326:135-150.

Hanks, D.L., E.D. McArthur, R. Stevens, and A.P. Plummer. 1973. Chromatographic characteristics and phylogenetic relationships of Artemisia, section Tridentatae. USDA Forest Serv. Res. Pap. INT-141.

Harvey, S.J. 1981. Life history and reproductive strategies in Artemisia. M.S. Thesis. Montana State Univ., Bozeman.

Holbo, H.R., and H.N. Mozingo. 1965. The chromatographic characterization of Artemisia, section Tridentatae. Amer. J. Bot. 52:970-978.

Kelsey, R.G. 1982. Rapid extraction of sesquiterpene lactones from sagebrush for use as taxonomic markers. J. Range Manage. 35:269.

Kelsey, R.G., M.S. Morris, and F. Shafizadeh. 1976. The use of sesquiterpene lactones as taxonomic markers in the shrubby species of Artemisia (section Tridentatae) in Montana. J. Range Manage. 29:502-505.

Kelsey, R.G., and F. Sharizadeh. 1980. Glandular trichomes and sesquiterpene lactones of Artemisia nova (Asteraceae). Biochem. Syst. Ecol. 8:371-377.

McArthur, E.D., A.C. Blauer, A.P. Plummer, and R. Stevens. 1979. Characteristics and hybridization of important intermountain shrubs. III. Sunflower family. USDA Forest Serv. Res. Pap. INT-220.

Nelson, A. 1900. New Plants from Wyoming. Bull. Torrey Bot. Club 27:258-274

Rydberg, P.A. 1916. Artemisia and Artemisiastrum. North Amer. Flora $34: 244-285$

Shultz, L. 1983. Systematics and anatomical studies of Artemisia subgenus Tridentatae. Ph.D. Diss. Claremont Graduate School, Claremont, California.

Ward, G.H. 1953. Artemisia, section Seriphidium, in North America, a cytotaxonomic study. Contr. Dudley Herb. 4:155-205.

West, N.E., R.J. Tausch, K.H. Rea, and P.T. Tueller. 1978. Taxonomic determination, distribution, and ecological indicator values of sagebrush within the pinyon-juniper woodlands of the Great Basin. J. Range Manage. 31:87-92.

Winward, A.H., and E.W. Tisdale. 1969. A simplified chemical method for sagebrush identification. USDA Forest Serv., Intermountain Region. Range Improv. Notes 14:1-4.

Winward, A.H., and E.W. Tisdale. 1977. Taxonomy of the Artemisia tridentata complex in Idaho. Idaho Forest, Wildl,, and Range Exp. Sta. Bull. 19.

Young, A.L. 1965. A chemical study of the taxonomy of section Tridentatae of the genus Artemisia. Wyoming Range Manage. Issue 198:2-9

Young, A.L., and O. Asplund. 1964. A biochemical and chemical taxonomic study of Artemisia. Wyoming Range Manage. Issue 193:70-72. 